\title{
Restorative Justice In Application For Crime Investigation Abuse In Polsek Middle Semarang
}

\author{
M.Gargarin Friyandi ${ }^{1}$ and Aryani Witasari ${ }^{2}$
}

The issues that will be reviewed by the authors in this paper are: 1) How can the application of Restorative Justice in the criminal investigation police persecution in the Middle Semarang?; 2) What are the obstacles in the implementation of Restorative Justice in the criminal investigation police persecution in the Middle Semarang; 3 ) What is the solution to implement Restorative Justice in the criminal investigation police persecution in the Middle Semarang? The method research approach used socio-juridical. Specification of the research is descriptive. The the type of data used is primary data, secondary data consisting of secondary legal materials and tertiary legal materials.

Based on the results of the study concluded that the application of Restorative Justice in the investigation of criminal mistreatment in police Middle semarang has been able to implement, but still refer to the existing rules that reduce the evidence to the non-fulfillment of the evidence in accordance with Article 184 Criminal Procedure Code so that the case can be implemented degrees termination of an investigation or SP3, Obstacles in the implementation of Restorative Justice in the criminal investigation police persecution in the Middle Semarang is the existence of internal factors and external factors that should be corrected so that Restorative Justice can be implemented without violating the rules. The barriers related solutions need to do is provide legal counseling, seminars, maximize the role of lower-level government officials related legal awareness in the community and maximize Bhabinkamtibmas role as the executive officer as well as representing the presence of the state in society.

Keywords: Restorative justice; Investigation; Crime of Persecution.

\section{Introduction}

The law in Indonesia was basically created to organize and direct human behavior or society towards good, it reduce in law, written or unwritten. The law has consequences that must be accepted punishment for violators of the law itself, from social sanctions, penalties and even criminal sanctions to imprisonment of violators of the regulation.

The laws that apply in Indonesia has several sources before independence already in force, inter alia derived from religious law, the law derived from custom or habit, and laws are sourced from other countries who colonized Indonesia. The third source of law is very closely related, and none can be separated from each other, because if the state law enforced in the area which upholds the common law, the existence of the

\footnotetext{
${ }^{1}$ Student of Master of Law, Universitas Islam Sultan Agung Semarang and Indonesian Police Sector Middle semarang, email: gargarinfriyandi@yahoo.com

${ }^{2}$ Faculty of Law Universitas Islam Sultan Agung
} 
law itself will collide with the community. It is highly inversely proportional to the purposes of the law itself which creates organize and direct people to the better.

In terms of law enforcement there is the expected goals of law enforcement, according to the law is enforced, Gustav Radbruch in order to achieve legal certainty, justice or expediency of the law against the parties. This is in accordance with the preamble to the Constitution of the Republic of Indonesia in 1945 and Pancasila in principle to two which reads Fair and Civilized Humanity ${ }^{3}$. This suggests that law enforcement should also be the fulfillment of a sense of justice and humanity for the parties who are running the law enforcement process either victims or perpetrators.

Effective law enforcement by Lawrance $M$. Friedman, there are three elements include the substance of the law, the legal structure and culture or culture ${ }^{4}$. The substance of the law contains the rules and laws that are used to catch criminals. The legal structure contains institutions authorized to carry out the regulations and laws that would have to have good human resources. Culture of Society implies attitudes and behavior towards their law upheld in society, are the people classified as law-abiding society or not.

Therefore, the authors have an interest in reviewing the concept of Restorative Justice to be applied in order to obtain justice. In this case the object is a crime against property as damages, which refund such losses become in fighting by the victim. Reviewing the legal regulations in force in Indonesia and the existing regulations in the Police related to the process implemented when cases reported resolved by way of Restorative Justice, as well as the steps made in relation to the implementation of the concept of Restorative justice can be carried out as well as see the role of law who live or Living Law which is still in hold dear by the people of Indonesia. Therefore, the author gives the title of this paper "Application of Restorative Justice in the Crime Investigation Police Persecution in Middle semarang".

The issues that will be reviewed by the authors in this paper are: 1) How can the application of Restorative Justice in the criminal investigation police persecution in the Middle Semarang?; 2) What are the obstacles in the implementation of Restorative Justice in the criminal investigation police persecution in the Middle Semarang; 3) What is the solution to implement Restorative Justice in the criminal investigation police persecution in the Middle Semarang?

\section{Research Methods}

The method research approach used socio-juridical. Specification of the research is descriptive.The the type of data used is primary data, secondary data consisting of secondary legal materials and tertiary legal materials.

In this research for data collection techniques required for analysis used interview techniques, literature, and study documents. Data analysis techniques in the study of this journal are data obtained through this research is descriptive.

\footnotetext{
${ }^{3}$ https://id.wikipedia.org/wiki/Pancasila, accessed on Thursday, March 22, 2018, 09:15 hours GMT.

${ }^{4}$ http://khoiruumah96.blogspot.co.id/2016/03/normal-0-false-false-false-en-us-x-none.html, accessed on Thursday, March 22, 2018, 09:14 hours.
} 


\section{Results And Discussion}

\subsection{Application of Restorative Justice in the criminal investigation police persecution in the Middle Semarang}

Restorative Justice in the implementation of the process of investigation of the property as a loss can not be implemented with the maximum given the umbrella law that does not exist or has not been clearly established and has not discount definite legal norm for its implementation. Application of Restorative justice who already have specific rules are implementing Diversion against children as perpetrators, it was enacted because children who commit a criminal act is a victim of the situation or the circumstances around it, it can be said that the contaminated children against arround the state to commit a crime.

In the discussion about the concept / system implementation of Restorative Justice, we must break down beforehand about the criminal justice system so that the concept / Restorative Justice system can be implemented. According Muladi, criminal justice system is a network judicial use of criminal law as a primary means, both material criminal law, formal pidan law, and criminal law enforcement ${ }^{5}$.

In the process of implementation Restorative justice in the investigation of criminal persecution in Polrestabes Semarang typically implemented by doing mediation between the complainant and reported to find the best solution for the incident. Can be said to be complainant and reported find their own solutions in accordance with what they agreed and then submitted to the investigating authorities for the failure by the case resolved by kinship or mediation.

On August 8, 2012 Kabareskrim Police issued a directive related to the settlement when both parties had agreed to be solved. Instructions and directives (jukrah) is contained in the Letter of Secret Telegram No. STR / 583 / VIII / 2012, dated August 8, 2012 on the application of the implementation of Restorative Justice. In accordance with the instructions in the TR (telegram) such that to abort or can not meet the elements of a case in accordance with Article 184 Criminal Procedure Code on the evidence that can be used as a basis to conduct an investigation into a case can be reduced so that the lack of evidence and then do SP3 by investigators.

On July 27, 2018 Chief of the Indonesian National Police, issued a circular letter number: SE / 8 / VII / 2018 dated July 27, 2018 on the Application of Restorative Justice in Criminal Case Settlement. The letter was issued in view of Restorative justice is not only meant as a method of termination case amicably, but the broader fulfillment of a sense of justice all those involved in criminal cases through efforts involving the victim, offender and community and investigator / investigator as a mediator, while the settlement one only in the form of a peace agreement and revocation of the right to

\footnotetext{
${ }^{5}$ Muladi, 2002, Kapita Selekta Sistem Peradilan Pidana, Semarang: Badan Penerbit Universitas Diponegoro, p.4
} 
sue and victims need to be requested by the public prosecutor's jurisprudence to abort attorney power of the victim and the public prosecutor.

\subsection{What are the obstacles in the implementation of Restorative Justice in the criminal investigation police persecution in the Middle Semarang.}

The obstacles in implementing Restorative justice experienced by the investigator and the investigator assistant Sat Reskrim Polrestabes Semarang is as follows:

- Internal barriers

Although the application of Restorative justice was becoming known as an alternative handling of criminal offenses and have enjoyed the support of many parties on implementation but many obstacles from the existing system, namely:

- Limited human resources of the investigator and the investigator aide in solving the case, more cases than the executor of both personal and facilities.

- An understanding of the concept of Restorative justice that has not fully entered into the thoughts of each personnel (old mindset oriented legal process which remain to be implemented).

- The absence of clear legal rules from the government so that there are no definite rules for implementing the rules on Restorative justice.

- Lack of cooperation between law enforcement authorities (the element of law enforcement with community care law / NGOs)

- The lack of a common perception among law enforcement concerning the application of Restorative justice that have been developed in the community.

- External barriers

In addition to the internal resistance of the police or there are also barriers that come from outside that could impede the implementation of Restorative justice, among others:

- Related peoples views Restorative justice processes are implemented will make the perpetrator is not a deterrent (for the perpetrators of the rich) because it can replace the loss of the need to undergo the process of law and punished.

- Trouble is an understanding of the relevant community Restorative justice processes.

- The persistently high ego properties owned by the same victim or perpetrator feel the most correct and will not budge.

Based on interviews with informants Unit investigator Idik / Resmob Ipda Dirga Abriawan, S.Tr.K., the maid investigators Aiptu Adi Gesit Satata, the maid investigator Bripka Ragil Tri Wibowo, SH, the operator of the process of the investigation of the offenses persecution account for Restorative implementation barriers justice, among others:

- At the time of inviting both sides, whether victims or perpetrators, where victims still feel received the treatment offenders who cause harm to the victim.

- Determining the right time and ensure for victims and perpetrators to be able to meet, between the victim and the perpetrator was hard to tell. 
- Demand compensation requested by the victim is not fair and does not match the capabilities offender.

The presence of the parties or the people that would benefit both parties who are litigants, so that will change the agreements that have been or will be determined.

But the application of Restorative justice in the investigation of criminal offenses against property in Polrestabes Semarang, it is necessary to remember the desire of each of the reporting the loss of which is returned to revoke the report, given that the police can not automatically be revoked if the loss is returned, it is not fair to the offender reported and have repaid the losses. Restorative justice so very right step if done to accommodate the desire of each litigants, because imprisonment is also not solve the problem, will revenge and so forth ${ }^{6}$.

\subsection{Solutions to implement Restorative Justice in the criminal investigation police persecution in the Middle Semarang.}

Based on the obstacles or barriers faced by the investigator and the investigator assistant Sat Reskrim Police Middle Semarang related to the application of Restorative Justice in the investigation of criminal offenses against property in Polrestabes Semarang, among others:

- Provide legal counseling to the public relating to the application of the principles of Restorative Justice to resolve a crime, so that people know and understand the principles of justice Restorative Justice. So that the police in implementing or give undertakings relating thereto have been no difficulty going to the understanding of justice Restorative Justice.

- Provide training or seminars on the police in particular investigator who handles criminal cases gradually and periodically, always to up date the regulations and laws relating to Restorative Justice. Human resources so as to create the investigator and the investigator helpers become increasingly dominate the process of implementation of Restorative Justice.

- Police must play an active and transparent in a way to open up to both parties, especially for the victims by providing a phone number (contact person) party litigants, so that the litigants can freely related communication problems.

- Held a legal seminar with other law enforcement agencies (prosecutors and courts) to equalize the perception related to the application of Restorative Justice.

- Providing legal seminar on society, in order to provide insight and understanding of the law and provide information related to the settlement out of court or Restorative Justice.

- Goverment apparatur maximize the role of the lower-level ie wards and district to provide an understanding of the legal and deliberations are now more popularly called Restorative Justice.

- Maximizing Bhabinkamtibmas role as a representative of the Police who are leading the state presence in the community, in order to understanding of the public about

\footnotetext{
${ }^{6}$ Interview on Thursday, January 17, 2019 at 10:00 pm in the police investigator Middle Semarang, Polrestabes.Semarang
} 
the problems which developed in the community to minimize the legal process continued by carrying Restorative Justice.

\section{Closing}

\subsection{Conclusion}

- Application of Restorative Justice in the criminal investigation police persecution in the Middle Semarang can already be implemented but still refer to the existing rules that reduce the evidence to the non-fulfillment of the evidence in accordance with Article 184 of the Criminal Code so that the matter can be implemented degrees termination of an investigation or SP3.

- Obstacles in the implementation of Restorative Justice in the criminal investigation police persecution in the Middle Semarang is the existence of internal factors and external factors that should be corrected so that Restorative Justice can be implemented without violating the rules.

- The barriers related solutions need to do is provide legal counseling, seminars, maximize the role of lower-level government officials related legal awareness in the community and maximize Bhabinkamtibmas role as the executive officer as well as representing the presence of the state in society.

\subsection{Suggestion}

In this paper we provide input and advice regarding the application of Restorative justice in the investigation of an offense that is to be made a definite rule of law so that the investigator can be guided by the rules and be able to carry out the investigation process.

\section{Bibliography}

[1] Muladi, 2002, Kapita Selekta Sistem Peradilan Pidana, Semarang: Badan Penerbit Universitas Diponegoro.

[2] Wikipedia Bahasa Indonesia, May 12, 2012, "Pancasila" https://id.wikipedia.org/wiki/Pancasila, accessed on Thursday, March 22, 2018, 09:15 hours GMT.

[3] Khoiru Umah, 30 Maret 2016, "Sistem Hukum Menurut M FRIEDMAAN "http://khoiruumah96.blogspot.co.id/2016/03/normal-0-false-false-false-en-us-xnone.html, accessed on Thursday, March 22, 2018. 